\title{
Popular Resistance in Cambodia: The Rationale behind Government Response
}

Young Sokphea*

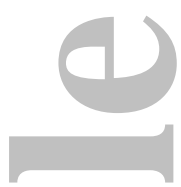

Abstract: Agrarian resistance often occurs as a result of expropriation and dispossession of poor farmers' land and other properties. This paper examines how cost-benefit rational choice determined the government of Cambodia's response to poor farmers' resistance to large-scale land acquisition for an agro-industrial investment. Theoretically, however government chooses to respond to resistance, the aim is to retain more benefits, especially

political legitimacy. In this study, the government, in collaboration with private companies, opted for a combination of strong repression and partial concession in response to the resistance by the communities. The study argues that this response is basically determined by cost-benefit calculations. However, the purpose is not to retain political legitimacy as theoretically argued, but to protect the economic interests of the client-patron networks that had developed between foreign companies and the powerful local politico-commercial personages associated with the regime.

\section{Keywords:}

Resistance, patron-client network, rational choice, repression, concession, Cambodia

* Young Sokphea is a PhD Candidate in the School of Social and Political Sciences at the University of Melbourne in Australia. His research interests are on contentious politics, social movements, Asian politics and political economy of natural resource management. His works appear in Georgetown Journal of Asian Affairs and Asian Journal of Social Science. Data presented in this paper were collected as part of the author's doctoral research, which was This is the author manuscript accepted for publication and has undergone full peer review but has not been through the copyediting, typesetting, pagination and proofreading process, which may lead to differences between this version and the Version record. Please cite this article as doi:10.1111/ aspp.12288. 
supported by Faculty of Arts of the University of Melbourne. The author would like to thank Kate Macdonald and Andrew Walter, and three anonymous reviewers for their insightful comments on earlier version of this paper.

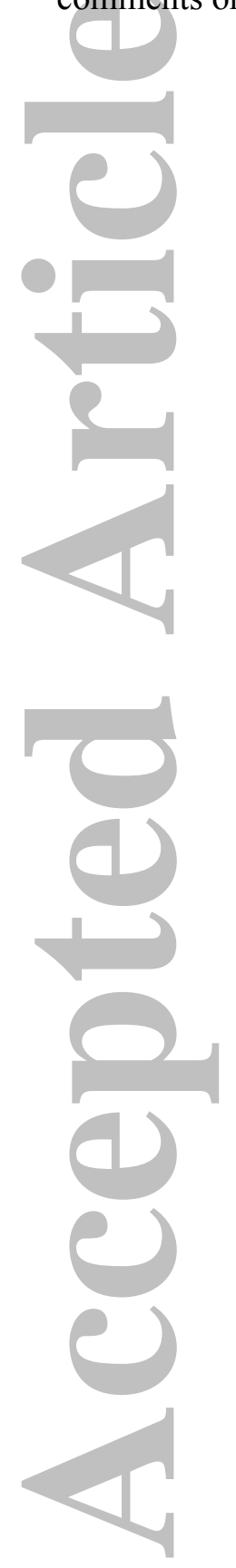




\section{Introduction}

Citizens' resistance is an important mode of political participation. Numerous people from different walks of life, including workers, farmers, community dwellers, and homeworkers, have resorted to this mode of action to protect and pursue their interests. While many studies have focused on the dynamics of the resistance of disgruntled groups, little attention has been paid to what determines the responses of the targets of resistance - in this case, government or private actors (Sokphea, 2016; Cress and Snow, 2000; Soule, 2009; McAdam and Tarrow, 2000). Some scholars suggest that the responses by the government or the State rely on the tactics or strategies of resistance. They argue that strong and innovative tactics tend to leverage influence on the government or private entities to concede (Gamson, 1990; Marx and McAdam, 1994; Chenoweth and Stephan, 2011). Another group of scholars suggests that cost-benefit rationales shape the responses of the State, claiming that the aim of each response, whether concession, repression, or a combination of both, is to retain more benefits. The most important benefit to retain is ensuring political legitimacy (Goldstone and Tilly, 2001; Cai, 2010). Although these propositions, to a certain degree, explain resistance cases in Western countries, they do not necessarily reflect the context of resistance in Southeast Asia.

In Cambodia, citizens' resistance occurs as a result of adverse changes in socio-economic conditions. Driven by improper policy implementation and regulatory enforcement, largescale land acquisition — either through buying or leasing large pieces of land by domestic or transnational companies, governments and individuals ${ }^{1}$ (see Borras et al, 2011; Messerli et al, 2015) - caused chronic contention between and among the deprived communities, the government and private actors who were involved. The affected communities have orchestrated collective actions to forward their demands, including but not limited to return of 
the land, acceptable cash compensation, respect for human rights, and others. In response, the government, in collaboration with private companies, employed different mechanisms of response. Some communities faced partial concessions from the government and companies, while others were suppressed by the government and its instrumentalities. So far, the factors influencing the responses of the government and companies have not been well studied in the literature on Cambodia (see Schneider, 2011; Schoengerger, 2015; Swift, 2015; Messerli et al, 2015; Diepart, 2015).

(2015; Diepart, 2015).

As a contribution to addressing this, this study draws on the popular and prolonged resistance of communities in southwestern Cambodia against large-scale land acquisition for

the agro-sugar industry. Based on secondary and primary data, ${ }^{2}$ the study postulates that, while the nature of resistance tactics and influencing strategies are important, cost-benefit rational choice appears to be more decisive in explaining the government response - a combination of partial concession and strong repression - towards the resistance by the communities. An important rationale underlying this response is the protection of patronclient networks, an entrenched relationship between the politico-commercial persons (middle patron) and the foreign companies (client), rather than retaining political legitimacy.

The remainder of this article is organized as follows. It begins by reviewing the literature and conceptualizing a theoretical and analytical framework to explain and analyze the phenomenon of resistance as well as cost-benefit rational choice which shapes the government response. Following this section, the article empirically explores and explains community resistance, and factors stimulating the government and companies' responses to the communities. Last but not least, the article draws conclusions on how cost-benefit rational choice, in terms of protecting patron-client networks, determines both the government response and the consequences of the communities' resistance. 


\section{Resistance and Factors Rationalizing Government Response}

In social movements, a resistance or a movement occurs as a result of rapid changes that affect the interests of a particular community, a group of people, or organization (McCarthy and Zald, 1977). The goal of citizen resistance is to affect changes in particular things in the society, usually, but not always, conducted by a group of people with a particular interest and goal. Resistance is often known as a way by which the population or powerless can restrict and sever the source of power of their rulers or other oppressors, and mobilize their own potential power into effective power (Sharp, 2005). Although resisters tend to avoid violence, it is a challenge for them to avoid conflict, especially violent measures undertaken by the targets (Daniel, 2015). Though the target of a resistance remains debatable, Tilly (2004), Soule (2009) and Sokphea (2016) claim that movements target not only government authorities or the state, but also the business sector.

In response, different governments choose different mechanisms to address resistance. Cai (2010), in his work on China, conceptualizes four mechanisms of response: (i) concession: the resisters' demands are addressed; (ii) concession with discipline: the resisters' demands are met but some or all participants are punished; (iii) tolerance: the resisters' demands are ignored, but the target audience also tolerates the resistance; and (iv) repression: the resisters' demands are ignored, and some or all participants are punished. Though these mechanisms of response have been clearly framed by such scholars, factors determining these responses remain contested. A number of factors, including influencing strategies, costbenefit rationale and patronage and clientelism, have been suggested to be determinants of the government's responses.

Scholars suggest that to influence a government or state, several resistance tactics and strategies might be used - for example, institutional versus non-institutional actions, legal versus illegal action, violence versus non-violence (Marx and McAdam, 1994; McAdam and 
Tarrow, 2000), and non-disruptive versus disruptive tactics (Cress and Snow, 2000; Gamson, 1990). These categories can be condensed as non-institutional and institutional tactics or nonviolent and violent tactics (Sokphea, 2016). While sit-ins, road blockage, violent actions, and other harmful actions are deemed as non-institutional tactics, activities such as peaceful protests, boycotts, marches, petitions, lawsuits, and other means endorsed by a particular state or government are recognized as institutional tactics (Marx and McAdam, 1994). Even though both types are prominent in resistance studies, many scholars assert that non-violent or institutional tactics tend to be more effective compared with violent ones (Chenoweth and Stephan, 2011). However, there are also those who suggest that violent actions tend to work in particular circumstances, such as those involving regime change or revolution (Gamson, 1990; Davenport, 2007).

Influenced by rational choice theories, Goldstone and Tilly (2001) and Cai (2010) postulate that choosing the response mechanism relies on cost-benefit rationales. Goldstone and Tilly (2001) argue that a government response may swing back and forth between concession and repression or a combination of both in order to quell resistance. They hypothesize that if repression costs less than concession, a government may prefer repression, and vice versa. Further to Goldstone and Tilly (2001), Cai (2010) contends that there are two types of costs when a government concedes: economic and/or political costs, and signs of weakness; and two types of benefits: stopping resistance, and gaining legitimacy. Redressing citizens' concerns requires financial resources, thus it is government's economic burden. Likewise, if addressing citizens' concerns requires policy reform or corrections in policy implementation, it is a political burden of the government. Another cost of making concessions is showing signs of weakness by acknowledging a government's malfeasance. But the benefit from making concessions is that a government stops resistance and gains legitimacy (recognition of government) (Cai, 2010). As a benefit, the repression deters 
resistance of citizens; as a cost, it increases illegitimacy perception, and risks of repressive measures. For example, if a government represses legitimate claims of citizens, the citizens will perceive government as illegitimate. Ineffective repressive measures might cause serious regime threats. If repressive measures orchestrated by a government fail to stop resistance completely, it provokes stronger resistance against that government, and thus, could lead to social instability (Cai, 2010).

rocialinste

Whatever mechanism of response is employed, a government has to bear both costs and benefits. But the most important benefit to retain is maintaining political legitimacy of the government. While many scholars define legitimacy differently (see Lipset, 1981; Michelman, 2003; Michelson, 2005), generally, it is interchangeable with "satisfaction with", "trust in", and "favorable attitudes towards" a government, according to Michelson (2005, p.2). This study understands political legitimacy as a political system's worthiness to be recognized by citizen through the electoral system (Michelman, 2003). In this instance, a government's response will entail either loss or retention of political legitimacy (Cai, 2010).

While cost-benefit rationale appears to be a plausible explanation why a government opts for a particular response, patronage and clientelism - as derived from the seminal works of Scott (1972a, 1972b) in Southeast Asia-have not been properly investigated by Southeast Asian scholars as explanations for the responses of the government or target entities to resistance. Clientelism implies a dyadic and asymmetrical/unequal relationship between the patron and the client, while patronage is understood as the relationship between an individual person and a larger group (Scott, 1972a, 1972b). But Hicken (2011) argues that, in patronage, the patron must hold a position in an office that has access to state resources. In clientelism, a patron may or not hold position in such an office and so may not be able to deliver public resources, but must rely on alternative means of exchange, including private and party resources (Hicken, 2011). Despite these distinct characteristics, this study, as well as 
Kitschelt and Wilkinson (2007), consider patronage and clientelism to be frequently synonymous and used interchangeably.

According to Scott (1972a, 1972b), the patron-client relationship can be understood as a dyadic tie involving a largely instrumental friendship. In this friendship, an individual of higher socio-economic status (the patron) uses his own influence and resources to provide protection, or benefits, or both, for a person of lower status (the client) who, for their part, reciprocates by offering general support and assistance to the patron. This is clearly observed in rural and agrarian societies in Southeast Asia (Thailand, Malaysia, Myanmar etc.), where reciprocal although not equal flows of services and goods from patron to client and vice versa are common (Scott, 1972a). It is apparent that a client needs support from a patron either to avoid something or to gain something which otherwise would not be obtainable. Developing a clientelist network is a tool to gain protection and to achieve goals in a situation of societal uncertainty created by public institutions.

In his attempt to develop a typology of neo-patrimonial regimes in Southeast Asian and African countries, Bach (2011) asserts that state institutions are influenced by patronclient relationships. In countries such as Thailand, Indonesia, the Philippines and Malaysia, the relationships between state bureaucracy and private business are manifested in terms of cronyism, oligarchy, predatoriness and bureaucracy or rent (Bach, 2011). These patterns of relations are often seen in the neo-patrimonial regime (Sindzingre, 2012). The patrons award public or state resources to the clients to ensure loyalty or cultivate political support. In this system, the distinction between public and private spheres is formally and legally defined, but not always evident in practice (Bratton and Van de Walle, 1994).

\section{Political change and the effects of popular resistance in Cambodia}


Since the 1970s, Cambodia's political and economic systems have transformed over time: from civil war to peace, from a planned economy to a free market economy, and from communism to democracy (Hughes, 2003). Following the collapse of the Khmer Rouge in 1979, the UN organized a national election in 1993, in which the FUNCINPEC ${ }^{3}$ party won the majority of the votes, followed by the Cambodian People's Party led by Hun Sen. After a coup d'état organized by Hun Sen against the FUNCINPEC in 1997, CPP managed to win elections in 1998, 2004, 2008 and 2013. Hun Sen (PM) has until today retained his position as Prime Minister (cf. Un, 2015). As a result, some scholars claim that Cambodia's political regime is a hybrid one - neither a democratic nor authoritarian regime. For example, Pak et al (2007) and Un and So (2011) have classified Cambodia as a neo-patrimonial regime. In this regime, patron-client networks have been embedded not only within the government administration, but also within the everyday lives of Cambodians. These networks are built between several sectors in business and government, including fisheries, land resources, mining and oil sectors (Hughes, 2003; Pak et al, 2007; Sithirith, 2014; Un and So, 2009, 2011).

In 1993, Cambodia started to open its economy to attract foreign capital for development. In particular, foreign direct investment (FDI) skyrocketed from US\$242 million in 2001 to US\$10,891 million in 2008. After the global economic crisis in 2008, FDI increased again to US\$901 million in 2011, and US\$1,557 million in 2012 (World Bank, 2014). Despite the 2008 crisis, the trend of FDI in agriculture and related natural resources increased exponentially from US\$12 million in 2004 to US\$446 million in 2009 (CDC, 2010). Among other factors, the growth was driven by the government's sub-decree No. 146 on Economic Land Concession (ELCs) in 2005. The sub-decree aims to attract FDI for economic development, local employment and poverty reduction (RGC, 2005). 
Through ELCs, foreign investors are granted licenses for concessions for up to 99 years. As of late 2012, at least 2.6 million hectares $^{4}$ of land were acquired and granted to private corporations (both foreign and domestic investors, and joint ventures) under the ELC scheme (ADHOC, 2013). Out of 2.6 million hectares, 1,204,750 hectares were distributed by the Ministry of Agriculture, Forestry and Fisheries (MAFF) among about 122 companies (as of June 2012), and about 730,146 hectares among 133 companies were distributed by the Ministry of Environment (MoE) (Vannak, 2015). This large-scale land acquisition was possible because of joint ventures between foreign investors/corporations and powerful politico-commercial elites. In essence, the politico-commercial elites are acting as the "middle" patron with foreign investors as the client. With the support of the central patron, the middle patron is protected and so is the client. However, some of these joint venture investments, though not all, were accused of not only causing detrimental impacts on the livelihoods and culture of poor communities and violating basic human rights and the rights of indigenous communities, but also depleting the natural resources and damaging the environment (ADHOC, 2013; Un, 2009).

\section{Popular resistance and policy change}

Having been assisted by international and local NGOs, grassroots resistance has mounted since the early 2000s. Throughout the country, in both urban and rural areas, resistance has become a popular mode of leveraging influence to demand that government (provincial offices, ministries), private companies and other agencies remedy the adverse impacts.

About 770,000 people (including indigenous communities) have experienced indirect or direct adverse impacts and forced eviction (ADHOC, 2014), and have participated in resistance. Not only this study, but other studies have also suggested that the movements of 
these aggrieved communities, with the assistance of NGOs, have frequently encountered repressive responses from the government (especially provincial authorities) as well as private companies (ADHOC, 2013; NGO Forum, 2011; Sokphea, 2016). For instance, the government, in collaboration with foreign companies, represses communities and NGOs through the judicial system on the one hand (Un, 2009), and direct repressive measures, such as violently dispersing the protesters, on the other. According to ADHOC (2013), in 2012, 232 people were arrested in relation to land and housing issues. According to the NGO Forum (2011), several cases of land disputes have erupted between powerful or rich people and local protesters. Often, local or provincial authorities have intervened in the disputes by

intimidating and violently dispersing the protesters. Despite the lingering community resistance, the processes of large-scale investment in land, which is often known as rent extraction from natural resources, have persisted. They are secured in Cambodia because of strong backing from powerful government officials and local tycoons and elites who are involved in almost all foreign joint ventures.

(

Despite the harsh responses by the provincial authorities and police, the resistance of communities appeared to have influenced the central government's policies. On 07 May 2012, Prime Minister Hun Sen, in his Order No. 01BB on "Measures for Strengthening and Increasing the Effectiveness of the Management of Economic Land Concession", called for a temporary countrywide moratorium on ELCs (RGC, 2012). The Order attempts to revoke inactive and exploitative ELC licenses. Meanwhile, additional ELCs were still granted on the grounds that they were already in the process before the Order. Though people cited different reasons behind the Order, NGOs and community dwellers claimed that it was apparently the consequence of the campaign of NGOs and large community protests, complaints and petitions. ${ }^{5}$ These activities might have led to social unrest and might have threatened the Hun Sen regime if left unsolved (Sokphea, 2016; Subedi, 2012). 
An excerpt of the Order follows (RGC, 2012):

All ministries, institutions, and authorities must implement the government's policy regarding land concessions, and they must ensure that land concessions do not affect communal land or the daily life of the community... Those companies that have already (cectiver

received licenses from the government, but have failed to honour their contracts..., encroached on the land of the people..., abused villagers, or abused communal land will have their contracts revoked...

Even as the effectiveness of the moratorium on ELCs is subject to criticism (Sokphea, 2016), some exploitative and inactive licenses have been revoked by the concerned ministries and environmental related regulations were re-enforced. By 2015, MoE, for example, announced the revocation of 23 ELCs in 12 provinces, constituting about 90,000 hectares (Titthara, 2015). Meanwhile, MoE transferred some of the revoked ELCs to other companies with a reduced concession period of 50 or 70 years (Vida, 2015; Pheap, 2016). Revocation of ELCs awarded by MAFF has also taken place but no exact figure has been published.

In addition, the Order aims to excise land like leopard skin from ELCs that overlaps with land of communities and individual farmers. To do so, a number of volunteer students were sent to all provinces to demarcate and reallocate land with official land tittles to the rightful claimant farmers or households. As of May 2013, 540,000 hectares, nearly 175,000 hectares of which were cut out of 88 ELC companies, were demarcated and re-allocated to the individual farmers or households (MLMUPC, 2013). An NGO report published in July 2015 found that the review and cancellation of ELCs merely targeted dormant concessions but avoided concessions involved in land disputes (ADHOC, 2015). Researchers hired by the NGO Forum also found similar issues (Grimsditch and Schoenberger, 2015). To better 
understand the dynamics of the resistance, the responses and the factors stimulating the responses of the government, this study illustrates a case of lingering resistance against a large-scale land acquisition for an agro-sugar industry in Cambodia.

\section{Research methods}

Among other cases, community resistance against an agro-sugar industry project in Chikor Leu commune, Sre Ambel district, Koh Kong province was chosen because, in addition to its lingering resistance, it is known by NGOs as a model of resistance by disgruntled communities in Cambodia. Lessons from this case were drawn by a number of NGOs and advocates for application with other cases in the country. In addition to a review of literature, in-depth interviews with twenty key informants who represent all stakeholders involved in the dispute (company, government, NGOs and community) were held. Two interactive focus group discussions were conducted to collect empirical evidence from the case. The informants included three community activists, four NGO staff, nine local and senior government officials (including ELC secretariat), two company staff, and two academic and independent researchers (see appendix). Ten villagers from diverse backgrounds were invited to participate in each interactive focus group discussion. The key informants from NGOs and government were selected based on snowball sampling. Two senior staff of the two companies were directly approached for interviews. Meanwhile, three community representatives from the three villages which were affected by the land acquisition, were interviewed. All interviews were audio-recorded and names of respondents were anonymized to comply with research ethics requirements. The fieldwork began in August 2013 and was completed in January 2014. To analyze the empirical evidence, the study employed a qualitative process-tracing method that focuses on explaining the dynamics and consequences of resistance of the communities. Process tracing is a method of analyzing causal factors that 
explain outcomes of an interactive event or phenomenon (Beach and Pedersen, 2013). Time element is part of this causal analysis; this study covers the dynamics of resistance and interactions from early 2006 until early 2014 only.

\section{Resistance against an agro-sugar industry project in Cambodia: Influencing strategies and responses}

In Koh Kong province, the government has since 1998 given ELCs to about twelve companies for agro-industrial projects and other investments. As of 2012, these ELCs constitute about 120,000 hectares of Koh Kong. In 2006, the government granted about

20,000 hectares as ELCs to two joint-venture companies ${ }^{6}$ of a Cambodian senator and Taiwanese as well as Thai investors. These ELCs were granted for 90 years for sugarcane plantation and constructing a sugar-processing factory. Located in Chikor Leu commune, Sre Ambel district, Koh Kong province in South-western Cambodia, these ELCs were granted by $\mathrm{MAFF}^{7}$ on behalf of the government or the Council of Ministers [CoM], with the PM as chair (1)

or central patron. To be granted these ELCs, seeking approval from the provincial office of Koh Kong, which directs the village, commune and district levels, is unavoidable. Once approved by the provincial office, the proposal is sent to and endorsed by MAFF prior to the approval of CoM. ${ }^{8}$ In doing so, the CoM and PM, besides MAFF, play important roles in decision making and directing its subordinate institutions, especially MAFF and the provincial office, to manage and monitor these ELCs.

Before 2012, the senator owned about $20 \%$ of the shares, $50 \%$ belonged to a Thai company and the rest belonged to a Taiwanese company. It is claimed that the senator recently sold his $20 \%$ to the Thai company (Pellechi, 2012) and the remaining shares still belong to the Taiwanese. However, communities and NGOs believe that the senator still manages and influences this joint venture company. The communities claim that he is the one 
who has caused negative impacts on the communities. ${ }^{9}$ Operations caused detrimental impacts on all four villages of Chikor Leu commune, which is home to about 751 households with 3,673 people $(2,032$ females $) .{ }^{10}$ Having resided in the commune since the collapse of Khmer Rouge in 1979, ${ }^{11}$ these communities' sources of livelihoods are rice cultivation, collecting non-timber forest products (resin, vegetable, mushroom, wild fruits, rattan etc.), cattle and livestock raising, and short-term and long-term crop plantations (cashew nut, banana, and watermelon). With abundance of arable land and being surrounded by forest, focus group discussions suggest that they enjoyed prosperous livelihoods without interruption from land grabbing. ${ }^{12}$

Unfortunately, however, in May 2006, the sugar companies' bulldozers accompanied by the armed forces, without prior consultation nor proper social and environment impact assessments, ${ }^{13}$ cleared villagers' plantations, paddy fields and forests. Since then, the affected communities resisted against these adverse changes. ${ }^{14}$ The aim was to influence the government, as well as the sugar companies, to address their demands as explained below.

- To return their land after the sugar company endorsed by the government confiscated about 5,000 hectares of land that previously belonged to about 600 households. ${ }^{15}$ The communities believed that land is everything; loss of land is loss of occupation and income;

- To be compensated either in cash or land swap. If their land will not be returned, the government has to provide a replacement plot of land for them, or otherwise offer appropriate cash compensation, and

- To remedy adverse impacts on their livelihoods.

To influence the government to address their demands, the communities employed several tactics, such as peaceful protest, petition, filling complaints with the provincial court, 
and networking with NGOs. Since 2006 and almost every year till the present, they organized peaceful protests and road blockages, which attracted a number of local and international media agencies. In September 2006, the protest of the communities was confronted with strong repression by armed security guards who consisted of military personnel and policemen. They shot at the crowd, injuring one woman, and assaulted four others. ${ }^{16}$ Besides that, in the same year, policemen also attempted to arrest some community representatives, but they escaped and hid in the forest. ${ }^{17}$

Despite these simultaneous repressive measures, the provincial office collaborated with the sugar companies to offer cash compensation. They set up a committee composed of the representatives of the affected communities, commune councillors, the sugar companies and provincial officials to assess the value of the land based on market prices. But the provincial office and companies tended to determine everything, especially the amount of cash compensation. Households with proper documented records of occupying the land and with evidence of crop planation each received about US\$50 to US\$150, regardless of the size of land lost. The amount was not enough for them to afford another plot of land at the current market price to replace the plots grabbed by the companies. ${ }^{18}$ In late 2006 , the provincial office successfully lobbied 48 families to accept this cash compensation. Some communities however claimed that the provincial officials and companies threatened that "if they did not accept the cash, they would receive nothing." 19

In 2007, the communities petitioned the National Senate and National Assembly of Cambodia, Ministry of Justice, Ministry of Interior (MoI), Council of Ministers, and Cabinet of PM. These institutions accepted the petitions and promised to address the affected communities' demands, but no actions were undertaken afterwards. In January 2007, approximately 2,879 people filed a lawsuit against MAFF as well as the sugar companies with the provincial court of Koh Kong. The court accepted the complaints, but took no further 
action. Influenced by the senator, the court transferred the case to the Provincial Department of Land, and then to the provincial office. These were done in order to delay the response, in an attempt to weaken the resistance of the communities. In mid-2007, the provincial office and MAFF negotiated with the sugar companies to increase the cash compensation to US\$202 per household; about 361 households were successfully lobbied to accept it. Two reasons compelled these families to accept the cash: they felt hopeless because of the delay in the responses by the Government and their livelihoods were gradually worsening during that time.

In March 2008, the Secretary of State from MoI intervened in the dispute. He proposed two hectares of land swap for each household. But no one accepted because the location was far from the communities and the size and soil fertility (outcrop) were not compatible with the former ones. He later withdrew from the mediation process because of the influence of the senator. ${ }^{20}$ In mid-2008, to subdue the remaining resisters, the provincial office negotiated with the sugar companies to increase the amount of cash compensation to US\$880 per household. Although the amount remained low, for the above reasons, 112 households accepted this offer.

The remaining resisters resorted to assistance from local and international NGOs. The local NGOs provided legal advice, empowered the communities through various legal and advocacy trainings, and organized exposure visits inside and outside the country. A network of affected sugarcane communities was then established in three provinces, namely Koh Kong, Kampong Speu, and Oddar Meanchey, where sugarcane plantations were operating. Even though these empowered the representatives to be outspoken, the government officials claimed that these representatives were opposition party activists that instigated the communities to mobilize against (and to overthrow) the legitimate government. ${ }^{21}$ 
In 2009, the sugar companies increased their cash compensation to around US\$2000 per household. About 39 households accepted the offer. Yet, this amount of cash remained insufficient to acquire another plot of land. ${ }^{22}$ The remaining families, along with assistance from NGOs, resorted to various influencing strategies to elevate their influence.

\section{Shifting influencing strategies and responses}

In 2010, the local NGOs realized that the raw sugar was being exported from Cambodia to its parent company in Thailand, namely Khon Kaen Sugar Industry (KSL), for final refining.

The sugar was then exported to the UK through the European Union's Everything But Arms (EBA) scheme. ${ }^{23}$ In UK, the sugar was sold to Tate and Lyle (T\&L). Upon receiving this evidence, the communities and NGOs filed complaints with the National Human Rights Commission of Thailand (NHRC-T) to seek its intervention. In February 2010, the NHRC-T, after investigation, confirmed that KSL's subsidiary companies had breached the communities' economic rights and human rights (Peter and Pheap, 2013). As an excuse, KSL claimed that its Cambodian partner (the senator) had already remedied the issues. However, KSL was willing to solve the problem by providing cash compensation. If the villagers wanted their land back, KSL was happy to return the land until the Government (especially MAFF) compensated them with other lands. In the same year, the sugar companies established a corporate social responsibility department. Although the department assisted with school repairs and construction, the rehabilitation of roads and other activities proposed by the districts, communes and villages, ${ }^{24}$ they did not address the demands of the communities.

In early 2012, the NGOs, on behalf of the communities, wrote letters to T\&L to complain about the adverse impacts of its sugar suppliers in Cambodia. ${ }^{25}$ T\&L failed to verify 
these allegations and denied responsibility for any adverse impacts of its suppliers. In May 2012, 200 families from the communities filed a complaint against T\&L with a UK court. So far, there has been no progress in the case. In the same year, finding out that $T \& L$ was a member of Bonsucro, ${ }^{26}$ to leverage extra pressure the NGOs wrote a letter to Bonsucro to complain about how T\&L purchase of sugar was linked with human rights violations and impacts in Cambodia. Bonsucro terminated T\&L from its membership in $2012^{27}$ as it failed to address the allegations. Following termination, T\&L sold its sugar business to the American Sugar Refinery (ASR). The communities and NGOs then complained to ASR, but there was no positive response.

To reiterate, in May 2012 the government issued a moratorium on ELCs in Order No. 01BB to reallocate land overlapping with ELCs to the rightful claimant villagers. Unfortunately, the order was not enforced in Chikor Leu commune. The communities claim that, because of the power of the senator, the provincial governor of Koh Kong did not enforce the Order according to the PM and the affected communities' demands.

(1) In 2012, the communities, through the local NGOs, filed a complaint on the adverse impacts of the EU's EBA in Cambodia to the EU Delegation in Cambodia and in Brussels. In January 2014, the EU Parliament passed a resolution calling on its executive body to act on EU's EBA scheme that induced high risk of human rights violations in Cambodia. Later, an EU Member of Parliament officially visited Cambodia and uncovered the serious impacts of the agro-sugar industries. In response, the Minister of Commerce led a meeting and set up a working group to solve the sugar issue (Reaksmey and Petter, 2014). So far, there has been no significant progress made by EU's efforts and those of the working group.

As of late 2012, the sugar companies increased the cash compensation to about US\$3120 per household. Although it remains low, the aim was to lobby the communities to accept cash and to cease their protests and complaints. ${ }^{28}$ In particular, 21 households later 
opted for the offer. As of late 2013, the cash compensation was again increased to more than US\$3120 per family, but none of the families accepted the offer because the communities were confident with the UK court and EU's intervention.

\section{Consequence of resistance}

Evidence in the preceding sections suggests that, to achieve their demands, the communities employed tactical escalation from domestic influencing strategies - peaceful protests, petitions and filing complaints — to international strategies. The communities initially employed domestic influencing strategies to directly target the government institutions, such as the commune, district, provincial offices, MoI, national assembly and MAFF in the hopes of them regulating the sugar companies to address their demands. Since these strategies did not achieve fruitful outcomes besides inadequate cash compensation and repressive responses, the communities resorted to NGOs and staged international influencing strategies to directly influence the sugar companies and stakeholders at each stage of the sugar supply chain, and to indirectly influence the government. Although their international influencing strategies were strong, the communities did not receive any fruitful responses except the cash compensation. They suffered much delay and were accused of being part of the opposition party. With these responses, the resistance of the affected communities appears to have failed to achieve most of their demands: restitution of their land, acceptable cash compensation and other remedies for the adverse impacts to their livelihoods. They failed because their resistance encountered strong repression and partial concession by the government and sugar companies. 


\section{Rationales of government responses: strong repression and partial concession}

This section argues that the government's combination of strong repression and partial concession is based on a cost-benefit rationale as suggested by Cai (2010), rather than influencing strategies and tactics. However, the most important rationale is not about maintaining or gaining political legitimacy, but protecting patron-client networks between the politico-commercial person and the foreign investors.

\section{Failure of influencing strategies and tactics}

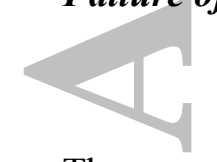

The communities initially believed that domestic influencing strategies would be effective tools to exert influence on the government so that they may pressure the sugar companies to address their demands. Although these strategies appear to be necessary as part of the dynamics of the resistance, they did not influence the government, especially the provincial office and MAFF. Instead, as in 2006, armed forces from the provincial office and armed guards from the sugar companies violently repressed the peaceful protests by the communities. Several petitions that were submitted to the commune, district and provincial offices and the national assembly did not receive any fruitful result besides "empty promises". ${ }^{29}$ Likewise, complaints filed with the provincial court did not produce any result except for postponement and diversion of the case to various institutions. There was no positive response because these institutions appeared to be influenced by the symbiotic relationship between the sugar companies and the powerful senator. Although the amount of cash compensation in 2010 was an increase from 2006, the amount remained low and other demands were not fulfilled.

To leverage their influence, the communities networked with NGOs and escalated to 
international influencing strategies. These strategies, including organizational networking, tracing supply chains and drawing the support of NGOs, aimed to directly target the sugar companies and indirectly target the government. In collaboration with the NGOs, the communities filed complaints against the stakeholders at each stage of the sugar supply chains, consisting of complaints to buyers in the UK, the sugar companies in Thailand and the EU's EBA program. While these strategies leveraged certain influence, they did not produce any satisfactory results. The amount of cash compensation was increased in 2013, but it was still low. Meanwhile, other demands (livelihood, land) of the communities were not addressed. These influencing strategies (organizational networking, external support, domestic protests, petitions, filing complaints) failed to leverage significant pressure and failed to decisively explain why the government, in collaboration with the sugar companies, opted for a combination of strong repression and partial concession.

\section{Cost-benefit rationales: to protect patron-client networks}

$$
\text { Cost }
$$

Taking

Taking a rational choice perspective into account, the aforementioned response mechanism was chosen because the government perceived that it would incur more benefits than costs. While Cai (2010) suggests that an important benefit to retain was maintaining political legitimacy of the government, the evidence in this case suggests that the ultimate aim of this response was to protect the economic interests of the patron-client network embedded in this agro-industry.

In this instance, a combination of strong repression and partial concession was chosen to avoid economic and political costs but it provoked lingering resistance by the communities and caused a perception of illegitimacy. The government refused to offer full concessions to eschew malfeasance. Evidence showed that the government, especially MAFF, defended 
itself by claiming that all adverse impacts were remedied. ${ }^{30}$ This was the case when an opposition Member of Parliament invited the minister of MAFF to clarify issues at a meeting of the National Assembly in 2012. Apparently, government also aimed to protect the senator of the ruling party as elections were approaching in 2012 and 2013 for commune councils and national elections, respectively.

aimed to resolve the increasing grassroots community resistance. However, evidence from this case and other studies convince that the Order was not fairly enforced throughout the country (Grimsditch and Schoenberger, 2015; Diepart, 2015). In Chikor Leu commune, the volunteer students were asked by the provincial governor not to excise the overlapping land from the company's ELCs because he claimed that the students could exacerbate the dispute. ${ }^{31}$ In fact, the sugar companies were not punished because of the power of the senator. ${ }^{32}$ If the sugar companies were to be punished, it would prove that the senator accepted the allegations. Moreover, if full concession was chosen, the government, as well as the senator, would lose a large amount of money, and lose a big portion of ELCs. To defend the senator's companies, the government claimed that the demand for 5,000 hectares from the 20,000 hectares of ELCs was excessive. ${ }^{33}$ It would cost a lot to the government as well as the senator if the government were to fully concede. In particular, the sugar companies claimed that they would need to pay again for the land that they already paid for. ${ }^{34}$

In 2013, the EU reported that these sugar industries were exporting about US\$38 million worth of sugar to the EU market annually. ${ }^{35}$ The volume of sugar exports was anticipated to increase in the following years. This amount of rent is significant for those clients (or middle patrons) of the regime who financially support the central patron (or ruling party) to influence election results (Hughes, 2003; Un and So, 2009, 2011). In this case, the senator acted as middle patron who collaborated with foreign investors (Thai and Taiwanese) 
to extract more rent from the sugarcane investment. As the volume of rent is significant, all concerned institutions, the provincial office in particular, have to protect this political figure. To do so, the government opted for strong repressive measures. The government, like the companies, bore little economic and political costs. But this mode of response would either provoke or deter future resistance.

government violently dispersed their peaceful protests. ${ }^{36}$ Later, their more outspoken members were repressed by the concerned institutions of the government. However, these could not deter all of the communities from resisting. They instead provoked the remaining

households to pursue resistance in the following years. ${ }^{37}$ To reiterate, the strength of resistance has escalated since 2007, and shifted from domestic influencing strategies (in 2010) to international influencing strategies, although these have thus far leveraged no influence on the government and sugar companies to concede. Hence these more repressive than concessional responses did not deter the resistance, bit they affected the legitimacy of the government in the disputed areas.

Repressing rightful claims of resistance damages regime legitimacy. However, evidence shows that, although its legitimacy declined, the ruling government managed to win the election in Chikor Leu commune. An activist comments:

Why a majority of people in our villages who used to support Cambodian People's Party (CPP) supported Cambodian National Recue Party (CNRP) ${ }^{38}$ instead? Because CPP grabbed the villagers' land! But CCP won the election again, even though many people support CNRP. Why? ${ }^{39}$

Based on the results of the national elections (2008, 2013), and commune council elections $(2007,2012)$, the ruling party (CPP) still retained the majority of the votes in Chikor Leu commune. The result of commune election in 2012 in Chikor Leu commune showed that 
the ruling party's popularity increased $31 \%$ compared to 2007 . Meanwhile, the opposition party (CNRP) gained extra popularity of about $8 \%$ in 2012 compared to $2007 .{ }^{40}$ Hence, at the communal level, the ruling government still maintained the majority of the votes. Regardless of commune council elections, legitimacy of the ruling government declined slightly during the national elections. During the 2013 elections, the ruling party's popularity declined about $12 \%$ compared to the 2008 elections. In contrast, the popularity of the opposition party in 2013 surged dramatically by $140 \%$ compared to 2008 . Though the popularity of the ruling party showed opposite trend in both elections, it still controlled the commune. However, the party is not a legitimate ruler of the communities. As an interview suggested, this election

result did not reflect legitimacy of the ruling party's government in the areas, but why did they win the elections? An informal interview with the head of a polling station in the commune revealed that the ruling government won the election because it managed to bring military voters from other jurisdictions to vote in the commune. This clearly manifests unfair and non-transparent elections in the commune. Even though elections are recognized as a means to legitimize the ruling party's government, the electoral process in Cambodia is neither free and fair, nor at acceptable standards (HRW, 2015; COMFREL, 2013).

\section{Benefits: protecting patron-client network, deterring resistance or retaining legitimacy}

Given the above reasons, the government did not actually retain legitimacy. It is not convincing that repressing citizen's rightful demands incur more legitimacy. Although this response type has deterred a number of resisters, the resisters have not voluntarily ceased resisting and would return to protests in the future.

Evidence showed that coercive responses at the beginning could compel a number of affected communities' members not to participate in resistance. In particular, about 500 
affected communities' members who accepted the cash compensation, withdrew themselves from resisting. Yet they did not withdraw voluntarily since they were forced to accept low cash compensation. Meanwhile the remaining 200 households who refused to accept cash compensation have been demanding that government address their concerns. This persistence might attract those who had already accepted cash compensation to join the resistance again. retain its entire control in Chikor Leu commune but not in a legitimate way. The government's partial concession and strong repression incur vital benefits, that is, maintaining economic rents by the powerful member of the ruling party, rather than legitimacy. If the government made full concessions, the government would also gain legitimacy. However, full concession would not only acknowledge the government's malfeasance, but also cost rents for the ruling party's senator. Moreover, full concession might trigger additional demands from other communities, and would indeed cost the companies tremendously. This has explicit implications for those communities who resist against agro-sugar industries in Kampong Speu and Oddar Meanchey provinces, which are linked with a member of the ruling party. Recently, though companies in Oddar Meanchey province have withdrawn their operations, several reports suggest that they did not lose their money since they have compensated little (even nothing) to the communities. The land has not been returned to the communities (see Pye, 2015).

\section{Conclusion}

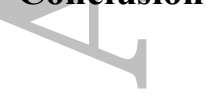

This paper has fleshed out the dynamics of interactions among the Government, companies and affected communities in pursuit of their respective interests. The affected communities employed various domestic influencing strategies, escalating from institutional means, 
including peaceful protest, petitions, lawsuit and networking, to international influencing strategies, such as filing complains to involved stakeholders at each stage of the sugar supply chain. These were initially employed to influence the Government in the hopes it would regulate the sugar companies, and later were orchestrated to directly influence the companies to address their demands.

between strong repression and partial concession; they repressed and later offered partial concessions and vice versa. Initially, the Government opted for strong repression: (i) violently dispersing peaceful protests, (ii) intimidating and threatening the communities and outspoken representatives (iii) procrastinating in the response to the communities, and (iv) accusing the communities of being involved in the opposition party's movement. Later, to partially concede, the government — in collaboration with the companies — shifted to offer cheap cash compensation. Although the cash compensation was seen as the residual impacts of the escalation of the communities' influencing strategies, because of livelihood issues and other threatening behaviour, a number of communities' members forced themselves to accept low cash compensation. While these responses shifted back and forth between concession and repression, the shift did not address all of the demands of the communities.

Overall, the resistance of the communities failed to achieve all their demands because the Government, in collaboration with the companies, apparently opted for a combination of strong repression and partial concession. The reason underlying why the Government opted for this mechanism of response is not decisively explained by influencing strategies or tactics as suggested by a number of scholars (see for example Gamson, 1990; McAdam, 1983). Influencing strategies (organizational networking, external support, supply chain approach) in this resistance were strong, but failed to influence the Government, as well as the companies, to fully concede. Opting for this mechanism of response was rather a result of thoughtful 
cost-benefit rational choice of the government vis-à-vis the companies' owner. However, the cost-benefit rationales behind the response was not about gaining political legitimacy of the government as suggested by Cai (2010) and Goldstone and Tilly (2001), but protecting the economic benefits of the patron-client network which formed between the foreign companies and a local powerful politico-commercial person. This is claimed on the grounds that it is implausible that repression of the communities' rightful resistance incurred more legitimacy. Although the ruling party's government managed to win the elections in the disputed areas, the elections were not organized in a fair and transparent manner and it did not reflect the perception of legitimacy by the communities.

This study concludes and argues that cost-benefit rational choice of Cai (2010) and Goldstone and Tilly (2001) shapes the government's responses, and ultimately determines the outcome of Cambodian popular resistance. However, an important rationale, rather than gaining legitimacy, is protecting the patron-client network in extracting rent. Protecting patron-client networks has long been seen in the context of the agrarian society in Southeast Asia as suggested by Scott (1972a, 1972b). This has implications for other cases in Cambodia where a combination of strong repression and partial concession is often chosen to respond to the communities' resistance in Kampong Speu and Kampong Chhnang provinces. For instance, the lingering case of Lar Peang community resistance against a company owned by the wife of a powerful (mine and energy) minister in Kampong Chhnang province has not been solved (see Mengleng, 2009). This community encountered more repressive measures because the involved government institutions tended to protect the economic interests of the political figure. In Kampong Speu, movements of the affected communities against the sugarcane investment received no significant results because strong repression was orchestrated to protect the powerful owner. To discourage rampant resistance in the country, the ruling government should take these issues into consideration and re-enforce relevant 
regulations in a more transparent and fair way. Deeper land reform is needed to discourage lingering resistance which might harm the regime and even cause political instability in the future.

\section{Appendix: List of Participants Interviewed}

\begin{tabular}{|c|c|c|}
\hline Codes & Position & Date \\
\hline $\mathrm{P} 01$ & Village Chief 1 & 03 Nov 2013 \\
\hline P02 & Executive Director-NGO & 06 Dec 2013 \\
\hline $\mathrm{P} 03$ & Former Commune Chief & 04 Nov 2013 \\
\hline P04 & Community Activist 1 & 01 Nov 2013 \\
\hline $\mathrm{P} 05$ & Deputy Governor of Koh Kong & 15 Dec 2013 \\
\hline P06 & Lawyer-NGO & 20 Dec 2013 \\
\hline P07 & Director of Provincial Department of Environment & 16 Dec 2013 \\
\hline P08 & Deputy Director of Provincial Department of Land Management & 02 Jan 2013 \\
\hline P09 & Village Chief 2 & 01 Nov 2013 \\
\hline $\mathrm{P} 10$ & Community Activist 2 & 02 Nov 2013 \\
\hline P11 & Village Chief 3 & 04 Nov 2013 \\
\hline $\mathrm{P} 12$ & Community Activist 3 & 01 Nov 2013 \\
\hline P13 & Chief Executive Finance Officer- the Sugar Company & 13 Jan 2014 \\
\hline P14 & Corporate Social Responsibility Manager- the Sugar Company & 13 Jan 2014 \\
\hline P15 & Independent Researcher & 26 Nov 2013 \\
\hline P16 & A University Lecturer & 02 Jan 2014 \\
\hline P17 & Provincial Manager-NGO & 16 Dec 2013 \\
\hline P18 & Provincial Manager-NGO & 04 Dec 2013 \\
\hline
\end{tabular}




\begin{tabular}{|l|l|l|}
\hline Codes & Position & Date \\
\hline P19 & Member of parliament and senior member of the ruling party & 17 Dec 2013 \\
\hline P20 & ELC Secretariat Official of MAFF & 26 Dec 2013 \\
\hline FGD1 & Village A (10 villagers) & 02 Nov 2013 \\
\hline FGD2 & Village B (10 villagers) & 02 Nov 2013 \\
\hline
\end{tabular}

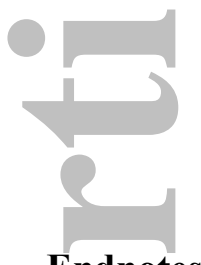

\section{Endnotes}

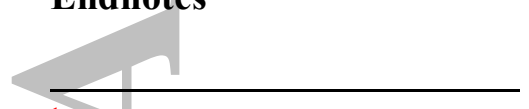

${ }^{1}$ Globally, the size of land varies considerably, but it is usually greater than 2 hectares; see Messerli, Giger, Dwyer, Breu and Eckert (2014). In Cambodia, the size is often bigger than 10,000 hectares and exceeding the Land Law's (2001) limitation.

${ }^{2}$ See description of the research methods.

${ }^{3}$ Front Uni Nationale pour un Cambodge Independent, Neutrale, Pacifique et Cooperatif

${ }^{4}$ The figure remains contested.

${ }^{5} \mathrm{P} 02$.

${ }^{6}$ To comply with research ethics required by the institution where the author is based, the real companies' names are not disclosed. Research participants had consented to author's use of pseudonyms only.

${ }^{7}$ In a letter dated 18 July 2006, Prime Minister Hun Sen delegated the task to the Minister of MAFF to sign contracts with the sugar companies.

${ }^{8}$ The Council for the Development of Cambodia (CDC) was also involved in approving the project, but it plays no important role in mediating conflicts with communities.

${ }^{9}$ Focus Group Discussion (FGD)1, FGD2 and P02 (please refer to the appendix).

${ }^{10}$ This figure is drawn from the commune database and discussions with commune councils.

${ }^{11}$ According to Land Law 2001, those who occupied the land 5 years prior to the effect of the 2001 law are legally entitled to own the land. These communities are thus legal owners of the land. On this ground, the communities are the rightful claimant.

${ }^{12}$ FDG1 and FGD2.

${ }^{13}$ P20. No impact studies were fully conducted before the operation of plantations.

${ }^{14}$ FDG01 and FDG02, P04, P10 and P12.

${ }^{15}$ FDG1 and FDG2.

${ }^{16} \mathrm{P} 04$ and $\mathrm{P} 10$.

${ }_{17} \mathrm{P} 02, \mathrm{P} 04, \mathrm{P} 10$ and $\mathrm{P} 12$.

${ }^{18}$ The land price keeps increasing in the commune. It was estimated to be at least more than US\$5000 per hectare.

19 P014.

${ }^{20} \mathrm{P} 02$.

${ }^{21} \mathrm{P} 05$ and $\mathrm{P} 08$.

${ }^{22}$ FDG01 and FGD02.

${ }^{23}$ EU's EBA emerged in 2001 to give 49 Least Developing Countries (LDC) full duty-free and quota-free access to the EU for all their exports with the exception of arms and armaments. The objectives of EBA trade preferences include "the promotion of sustainable development and good governance in the developing countries" according to EU regulations.

${ }^{24} \mathrm{P} 14$

25 P06. 


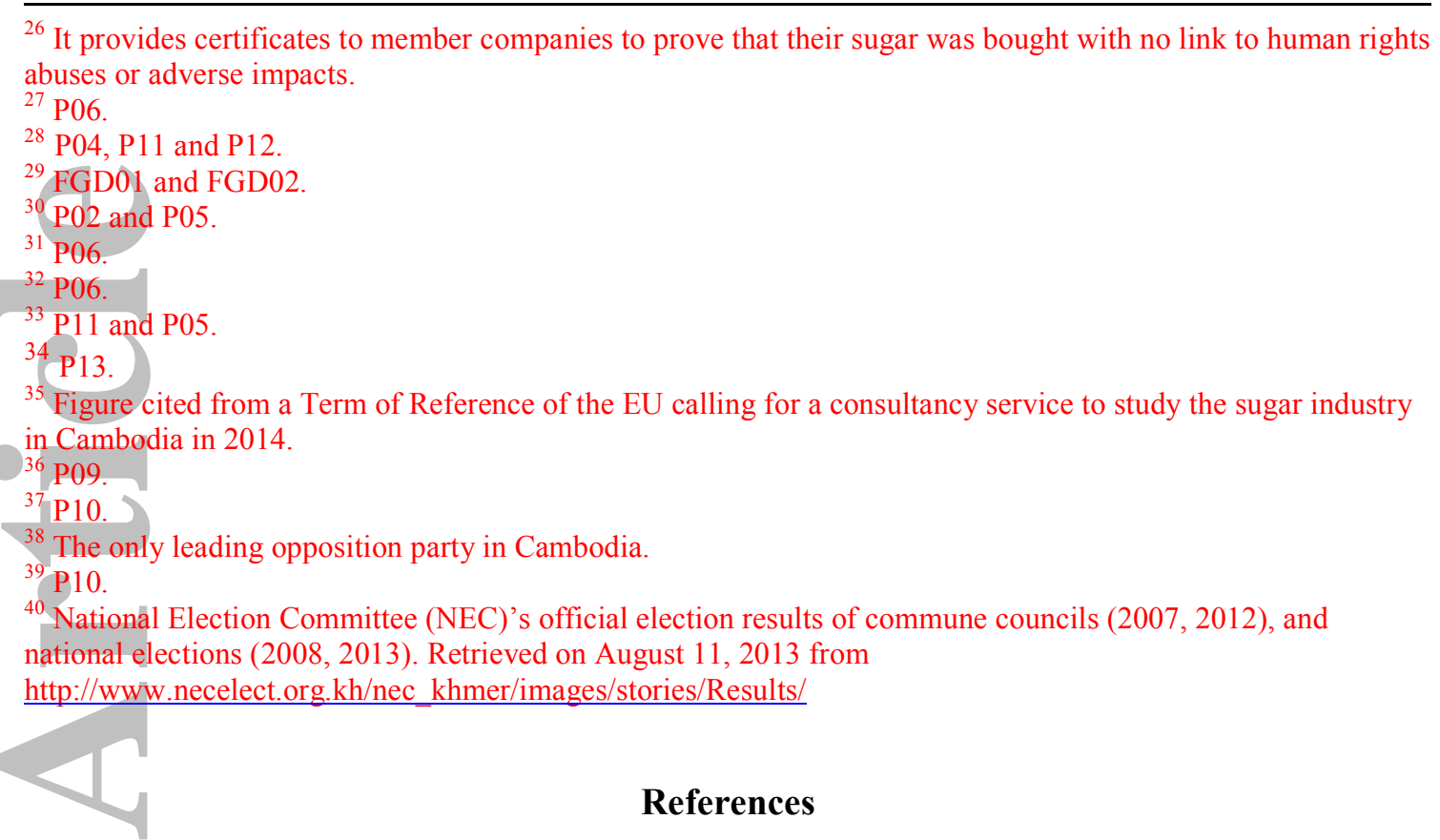

ADHOC (The Cambodian Human Rights and Development Association). (2013). A Turning Point? Land, Housing and Natural Resources Rights in Cambodia 2012. Phnom Penh: ADHOC.

(2015). Whose land? Report on the land rights situation in Cambodia: 2014 and first half of 2015. Phnom Penh: ADHOC

Bach, Daniel C. (2011). "Patrimonialism and neopatrimonialism: comparative trajectories and readings." Commonwealth \& Comparative Politics, 49(3), 275-294.

Beach, Derek and Pedersen, Ramus B. (2013). Process-Tracing Methods: Foundations and Guidelines. USA: University of Michigan Press.

Borras, Saturnino M; Hall, Ruth; Scoones, Ian; White, Ben and Wolford, Wendy (2011). "Towards a better understanding of global land grabbing: an editorial introduction." The Journal of Peasant Studies, 38(2), 209-216.

Bratton, Michale and Van de Walle, Nicolas (1994). "Neopatrimonial regimes and political transitions in Africa." World Politics, 46(4), 453-489. 
Cai, Yongshun (2008). "Power structure and regime resilience: contentious politics in China." British Journal of Political Science, 38(3), 411-432.

(2010). Collective resistance in China: Why popular protests succeed or fail. Standfor: Stanford University Press.

CDC (Councils for the Development of Cambodia). (2010). Cambodian Investment Board:

Projects by Sector Approved. Phnom Penh: CDC.

Chenoweth, Erica and Stephan, Maria J. (2011). Why civil resistance works: The strategic

logic of nonviolent conflict. New York: Columbia University Press.

COMFREL (The Committee for Free and Fair Elections in Cambodia). (2013). 2013 National Assembly Elections: Final Assessment and Report. Phnom Penh: COMFREL.

Cress, Danial M. and Snow, David A. (2000). "The outcomes of homeless mobilisation: The influence of organisation, disruption, political mediation, and framing." American Journal of Sociology, 105(4),1063-1104.

Davenport, Christian (2007). "State repression and political order." Annual Review of Political Science, 10, 1-23.

Diepart, Jean-Christophe (2015). The fragmentation of land tenure system in Cambodia: peasants and the formalisation of land rights. Paris: GRET, AgroParisTech and AGter

Gamson, William (1990). The strategy of social protest. Belmont, Calif.: Wadsworth Pub.

Goldstone, Jack A. and Tilly, Charles (2001). Threat (and opportunity): Popular action and state response in the dynamics of contentious action. In Ronald Aminzade, Jack A Goldstone, Doug McAdam and Elizabeth Perry (eds.), Silence and voice in the study of contentious politics (pp. 179-194). Cambridge, UK; New York: Cambridge University Press.

Grimsditch, Mark and Schoenberger, Laura (2015). New actions and existing policies: The implementation and impacts of Order 01. Phnom Penh: NGO Forum. 
Hicken, Allen (2011). “Clientelism.” Annual Review of Political Science, 14, 289-310.

HRW (Human Right Watch). (2015). 30 Years of Hun Sen: Violence, Repression, and Corruption in Cambodia. USA: HRW.

Hughes, Caroline (2003). Political Economy of the Cambodian Transition. London: Routledge.

Kitschelt, Herbert and Wilkinson, Steven (2007). Patrons, clients and policies: Patterns of r democratic accountability and political competition. New York: Cambridge University Press.

Lipset, Seymour (1981). Political man: the social bases of politics. Baltimore: Johns Hopkins University Press.

Marx, Gary T. and McAdam, Doug (1994). Collective behavior and social movements: process and structure. Englewood Cliffs, NJ: Prentice Hall.

McAdam, Doug (1983). "Tactical innovation and the pace of insurgency." American Sociological Review, 48(6), 735-754.

McAdam, Doug and Tarrow, Sidney (2000). "Nonviolence as contentious interaction.” PS: Political Science \& Politics, 33(2), 149-154.

McAdam, Doug; Tarrow, Sidney and Tilly, Charles (2001). Dynamics of contention. Cambridge; New York: Cambridge University Press.

McCarthy, John D and Zald, Mayer N. (1977). "Resource mobilisation and social movements: A partial theory.” American Journal of Sociology, 82(6), 1212-1241.

Mengleng, Ear (2009, Sept 24). Arrest Fears Keep Accused Land Dispute Leader Away from Court. The Cambodia Daily, retrieved on March 15, 2016 from https://www.cambodiadaily.com/archives/arrest-fears-keep-accused-land-disputeleader-away-from-court-64200/ 
Messerli, Peter; Giger, Markus; Dwyer, Michael B; Breu, Thomas and Eckert, Sandra (2014). "The geography of large-scale land acquisitions: Analysing socio-ecological patterns of target contexts in the global South." Applied Geography, 53, 449-459.

Messerli, Peter; Peeters, Amaury; Schoenweger, Oliver; Nanhthavong, Vong and Heinimann, Andreas (2015). Marginal Land or Marginal People? Analysing Patterns and Processes of Large-Scale Land Acquisitions in South-East Asia. In Christophe, Gironde; Christophe, Golay and Peter, Messerli (Eds.), Large-scale land acquisition: Focus on South-Eat Asia (pp. 136-171). Leiden: Brill

Michelman, Frank (2003). “IDA's Way: Constructing the Respectworthy Governmental System.” Fordham Law Review, 72(2), 345-365.

Michelson, Ethan (2005). Peasants' burdens and state response: exploring state concession to popular tax resistance in rural China. Bloomington: Indiana University.

MLMUPC (Ministry of Land Management, Urban Planning and Construction). (2013). Notification May 21, 2013, retrieved on February 06, 2016 from http://www.mlmupc.gov.kh/mlm/imgs/20130521\%20Announcement $\% 20$ of $\% 201$ legal $\%$ 20documents_Eng\%20-\%200pt.pdf

NGO Forum. (2011). Statistical Analysis on Land Disputes Occuring in Cambodia 2010. Phnom Penh: NGO Forum.

Pak, Kimchoeun; Horng, Vuthy; Eng, Netra; Ann, Sovatha; Kim, Sedara; Knowles, Jenny; and Craig, David (2007). Accountability and Neo-Patrimonialism: A Critical Literature Review. Working Paper 34. Phnom Penh: Cambodia Development Resource Institute. Pellechi, Gregory (2012, Aug 02). Koh Kong King Bowed out of 'Blood Sugar' Fairm. The Phnom Penh Post, retrieved on August 25, 2014 from http://www.phnompenhpost.com/national/koh-kong-king-bowed-out-'blood-sugar'-firm 
Peter, Zsombor, and Pheap, Aun (2013, Apr 17). Tate \& Lyle Defends Sugar Plantation Deal. The Cambodia Daily, retrieved on April 17, 2013 from http://www.cambodiadaily.com/archives/18834-18834/

Pheap, Aun (2016, Jan 19). Try Pheap Gets New ELC Amid Freeze, Governor Says. The Cambodia Daily, retrieved on March 15, 2016 from https://www.cambodiadaily.com/news/try-pheap-gets-new-elc-amid-freeze-governorsays-105822/

Pye, Daniel (2015, May 11). Sugar company pulls out. The Phnom Penh Post, retrieved on March 14, 2016 from http://www.phnompenhpost.com/national/sugar-company-pulls$\underline{\text { out }}$

Reaksmey, Hul and Petter, Zsombor (2014, Feb 11 ). Ministries to Help Farmers Hurt by

Sugar Plantations. The Cambodia Daily retrieved on March 03, 2016 from

http://www.cambodiadaily.com/archives/ministries-to-help-farmers-hurt-by-sugar-

plantations-51971/

Ritter, Daniel (2015). Civil resistance. In Donatella della Porta and Mario Diani (Eds), The Oxford Handbook of Social Movement (pp. 467-478). UK: Oxford University Press).

Royal Decree (2001) Land Law 2001. Phnom Penh: Royal Government of Cambodia

RGC (Royal Government of Cambodia). (2005). Sub-decree No. 146 on Economic Land Concessions. Phnom Penh: Royal Governnment of Cambodia.

(2012). Order 01BB on the Measures Strengthening and Increasing the Effectiveness of the Management of Economic Land Concessions. Phnom Penh: RGC.

Schneider, Alison E. (2011). What shall we do without our land? Land Grabs and Resistance in Rural Cambodia. UK: University of Sussex.

Scott, James C. (1972a). "The erosion of patron-client bonds and social change in rural Southeast Asia." The Journal of Asian Studies, 32(1), 5-37. 
(1972b). "Patron-client politics and political change in Southeast Asia." The

American Political Science Review, 66(1), 91-113.

Sharp, Gene (2005). Waging nonviolent struggle: 20th century practice and 21st century potential. Boston: Extending Horizons Books.

Sithirith, Mak (2014). "The Patron-Client System and Its Effect on Resources Management

in Cambodia: A Case in the Tonle Sap Lake." Asian Politics \& Policy, 6(4), 595-609.

Sokphea, Young (2016). "Movement of Indigenous Communities Targeting an AgroIndustrial Investment in North-Eastern Cambodia." Asian Journal of Social Science, 44(1-2), 187-213.

Soule, Sarah A. (2009). Contention and corporate social responsibility. New York: Cambridge University Press.

Steedly, Homer R. and Foley, John W. (1979). "The success of protest groups: Multivariate analyses.” Social Science Research, 8(1), 1-15.

Subedi, Surya P. (2012). A Human Rights Analysis of Economic and other Land Concession in Cambodia: Report of the Special Rapoorteur on the Situation of Human Rights in Cambodia. Phnom Penh: United Nations

Swift, Peter (2015). Transnationalisation of Resistance to Economic Land Concessions in Cambodia. Chiang Mai: Chiang Mai University.

Tarrow, Sidney (1998). Power in movement: social movements and contentious politics. New York: Cambridge University Press.

Tilly, Charles (1978). From mobilisation to revolution. Reading, Mass: Addison-Wesley. (2004). Social Movements, 1768-2004. Boulder: Paradigm Publishers.

Titthara, May (2015, Jan 15). Minister says 23 ELCs nixed. The Phnom Penh Post, retrieved on June 23, 2015 from http://www.phnompenhpost.com/national/minister-says-23-elcsnixed 
Un, Kheang (2009). “China's Foreign Investment and Assistance: Implications for Cambodia' Development and Democratisation." Peace \& Conflict Studies, 16(2), 65-81. (2015). “The Cambodian People Have Spoken: Has the Cambodian People's Party Heard?" Southeast Asian Affairs, 2015, 102-116.

Un, Kheang and So, Sokbunthoeun (2009). "Politics of Natural Resource Use in Cambodia." Asian Affairs: An American Review, 36(3), 123-138.

(2011). "Land Rights in Cambodia: How Neopatrimonial Politics Restricts Land Policy Reform.” Pacific Affairs, 84(2), 289-308.

Vannak, Chea (2015, Sept 30). Agricultural Ministry to End ELC Assessment in October. The Agence Kampuchea Press, retrieved on Feb 06, 2016 from http://www.akp.gov.kh/?p=69494

Vida, Taing (2015, July 29). Lifespan of ELCs slashed by gov't. The Phnom Penh Post, $\begin{array}{lllll}\text { retrieved on } & \text { December } & \text { 14, } & \text { from }\end{array}$ http://www.phnompenhpost.com/national/lifespan-elcs-slashed-govt

World Bank (2014). Online Data: Cambodia. Retrieved on March 14, 2015 from http://data.worldbank.org/country/cambodia 


\section{University Library}

\section{- M M N E R VA A gateway to Melbourne's research publications}

Minerva Access is the Institutional Repository of The University of Melbourne

Author/s:

Sokphea, Y

Title:

Popular Resistance in Cambodia: The Rationale Behind Government Response

Date:

2016-10-01

Citation:

Sokphea, Y. (2016). Popular Resistance in Cambodia: The Rationale Behind Government Response. ASIAN POLITICS \& POLICY, 8 (4), pp.593-613. https://doi.org/10.1111/ aspp. 12288.

Persistent Link:

http://hdl.handle.net/11343/291807 